\title{
Termination 1 Millennial-scale Rainfall Events over the Sunda Shelf
}

\author{
F. Buckingham1, S.A. Carolin ${ }^{1,2}$, J.W. Partin 3 , J.F. Adkins ${ }^{4}$, K.M. Cobb ${ }^{5}$, C.C. Day ${ }^{1}$, Q. \\ Ding $^{6}$, C. $\mathrm{He}^{7}$, Z. Liu ${ }^{7}$, B. Otto-Bliesner ${ }^{8}$, W.H.G. Roberts ${ }^{9}$, S. Lejau ${ }^{10}$, J. Malang ${ }^{10}$
}

${ }^{1}$ Department of Earth Sciences, University of Oxford, Oxford, UK

${ }^{2}$ Department of Earth Sciences, University of Cambridge, Cambridge, UK

${ }^{3}$ Institute for Geophysics, Jackson School of Geosciences, University of Texas at Austin, Austin, TX, USA

${ }^{4}$ Division of Geological and Planetary Sciences, California Institute of Technology, Pasadena, CA, USA

${ }^{5}$ Department of Earth and Atmospheric Sciences, Georgia Institute of Technology, Atlanta, GA, USA

${ }^{6}$ Department of Geography and Earth Research Institute, University of California Santa Barbara, Santa Barbara, USA

${ }^{7}$ Department of Geography, The Ohio State University, Columbus, OH, USA

${ }^{8}$ Climate and Global Dynamics Laboratory, National Center for Atmospheric Research, Boulder, CO, USA

${ }^{9}$ Geography and Environmental Sciences, Northumbria University, Newcastle-Upon-Tyne, UK

${ }^{10}$ Gunung Mulu National Park, Sarawak, Malaysia

Corresponding author: Stacy Carolin (sac219@cam.ac.uk)

\section{Key Points:}

- A new stalagmite record reveals for the first time distinct Bølling-Allerød and Younger Dryas oxygen isotope variations in northern Borneo

- The stalagmite oxygen isotope pattern strongly resembles the recent iCESM transient annual rainfall simulation from $20-11 \mathrm{ka}$

- Borneo drying during Heinrich 1 and the Younger Dryas may be attributed to an anomalous boreal winter Western North Pacific anticyclone

This article has been accepted for publication and undergone full peer review but has not been through the copyediting, typesetting, pagination and proofreading process, which may lead to differences between this version and the Version of Record. Please cite this article as doi: 10.1029/2021GL096937. 


\begin{abstract}
Recent paleoclimate reconstructions have suggested millennial-scale variability in the IndoPacific Warm Pool region coincident with events of the last deglaciation. Here we present a new stalagmite oxygen isotope record from northern Borneo, which today is located near the center of the region's mean annual inter-tropical convergence zone. The record spans the full deglaciation, and reveals for the first time distinct oxygen isotope variations at this location connected with the Bølling-Allerød onset and the Younger Dryas event. The full deglaciation in the Borneo stalagmite proxy reconstruction appears remarkably similar to a 20-11 ka transient simulation of rainfall over the area produced using the isotope-enabled Community Earth System Model. In this model, periods of weakened Atlantic Ocean meridional overturning circulation are associated with an anomalous Western North Pacific anticyclone, which is produced in boreal autumn and shifts south over Borneo during boreal winter, causing dry conditions.
\end{abstract}

\title{
Plain Language Summary
}

Here we aim to resolve conflicting evidence of how tropical convection in Borneo in the IndoPacific oceanic region, a critical region associated with El Niño events and the Asian and Australian-Indonesian monsoon systems, was affected by past changes in the strength of Atlantic Ocean circulation. Analyzing a 20,000+ year old Borneo cave calcite formation along its growth axis, we find large oxygen isotope shifts coincident with two prominent millennial-scale periods of reduced Atlantic Ocean overturning circulation strength. The isotope record is similar to a neighboring southwestern Philippine stalagmite record, and we interpret the signal as drier mean annual conditions over the region during these events compared to the background state; an interpretation supported by simulations in three independent state-of-the-art climate models. One model suggests that these conditions in Borneo were driven by the southwards shift of an anomalous anticyclone in the boreal winter season. By combining geochemical and model evidence, this study has shown that rainfall decreased for millennial periods during the end of the ice age, when the Atlantic Ocean overturning circulation weakened. In doing so, we have elucidated further how this region responds to major changes in global climate and ocean conditions.

\section{Introduction}

The Indo-Pacific Warm Pool (IPWP) is a critical region of the global climate system, associated with the Pacific and Indian Walker cells and the Asian and Australian-Indonesian monsoon systems. Partin et al. (2007) presented the first stalagmite $\delta^{18} \mathrm{O}$ record used to reconstruct convection changes over the IPWP spanning the region's transition from the Last Glacial Maximum to the Holocene. The $\delta^{18} \mathrm{O}$ record was constructed from three individual stalagmites, collected from Gunung Buda National Park cave systems in northern Borneo $\left(4^{\circ} \mathrm{N}\right.$, $\left.115^{\circ} \mathrm{E}\right)$. The strongest millennial-scale $\delta^{18} \mathrm{O}$ signal evident in all three records was a gradual shift through Heinrich Stadial 1 (HS1) to the highest $\delta^{18} \mathrm{O}$ values of the record, interpreted as a signal of weakening convection over the western tropical Pacific through this period. The record also demonstrated the warm pool's relatively smooth variability on both orbital and millennial timescales, in contrast to the abrupt shifts seen in mid-latitude Chinese stalagmite $\delta^{18} \mathrm{O}$ records (e.g. Wang et al., 2001).

A significant feature of the northern Borneo stalagmite record was the lack of a $\delta^{18} \mathrm{O}$ signal coincident with the Younger Dryas (YD) event, despite a clear HS1 signal (Partin et al.,

This article is protected by copyright. All rights reserved. 
2007). This appeared to suggest convection in the IPWP responded differently to the HS1 versus YD North Atlantic events (Partin et al., 2007), both of which are associated with a weakening of the Atlantic Meridional Overturning Circulation (AMOC) (e.g. McManus et al., 2004; Böhm et al., 2014; $\mathrm{Ng}$ et al., 2018). The YD conclusion at the time was based on a single stalagmite record, $\mathrm{SCH} 02$, as vertical growth in the other two Borneo stalagmites stopped prior to the YD event, and resumed after the event. A more recent study identified U-Th dating disparities in stalagmite SCH02 during Heinrich Stadial 4 (Carolin et al., 2013), warranting additional study of the Borneo rainfall response to millennial events of the last deglaciation. Indeed, other stalagmite records found in the IPWP in Sumatra, Indonesia to the west $\left(0^{\circ} \mathrm{S}, 100^{\circ} \mathrm{E}\right)$ (Wurtzel et al., 2018), Palawan, Philippines to the northeast $\left(10^{\circ} \mathrm{N}, 119^{\circ} \mathrm{E}\right)$ (Partin et al., 2015), and Flores, Indonesia to the south $\left(8.5^{\circ} \mathrm{S}, 120^{\circ} \mathrm{E}\right)$ (Griffiths et al., 2009; Ayliffe et al., 2013) all reveal distinct $\delta^{18} \mathrm{O}$ shifts coincident with the YD event.

Tropical climate perturbations associated with a weakened AMOC are proposed to result from processes such as a southward shift of the inter-tropical convergence zone (ITCZ) over the Pacific (Zhang and Delworth, 2005; 2007) or cross-basin interactions between the Atlantic and the El Niño-Southern Oscillation (ENSO) or Pacific Decadal Oscillation (Timmerman et al., 2007; Wang, 2019). To better understand underlying dynamics linking the AMOC with the local circulation change over the IPWP, a thorough analysis of the various proposed processes is needed. Improved climate proxy information in observation records that can be used in modeldata comparison contributes to this aim.

Despite the increasing number of stalagmite sites and proxy records, it remains challenging to interpret IPWP stalagmite $\delta^{18} \mathrm{O}$ records as changes in past rainfall amount and perturbations to large-scale atmospheric systems over the last deglaciation. This is largely due to the complexity of the maritime continent region. Under modern conditions, individual sites around the IPWP have unique rainfall patterns contributing to the mean annual rainfall $\delta^{18} \mathrm{O}$ value, as a result of the seasonal ITCZ migration, the intra-annual Madden-Julian Oscillation, and the Pacific and/or Indian Ocean Walker circulation cells' inter-annual variability (e.g. Moerman et al., 2013; Belgaman et al., 2017; Wurtzel et al., 2018; Konecky et al., 2019). During the last deglaciation, the Sunda Shelf was widely exposed (e.g. Hanebuth et al., 2000), placing the paleo-coastline further from some cave sites than modern, such as those in northern Borneo, and likely reorganizing regional circulation patterns (e.g. DiNezio et al., 2016; Windler et al., 2020). Fully-coupled general circulation model simulations with enabled water isotopes is a tool that can be utilized to assist with IPWP stalagmite $\delta^{18} \mathrm{O}$ interpretations (e.g. Windler et al., 2020; Du et al., 2021).

Here we present a new northern Borneo stalagmite $\delta^{18} \mathrm{O}$ record, the first from the area with continuous growth through the last deglaciation, to test for climate responses in the IPWP to changes in AMOC and associated climate events in the North Atlantic. The stalagmite contains clean calcite that is ideal for U-Th dating, and has previously demonstrated its ability to capture millennial scale events through the last glacial period (Carolin et al., 2013). We use a recent transient simulation of the evolution of global climate and water isotopes over the last deglaciation (He et al., 2021a) to investigate if the new Borneo stalagmite $\delta^{18} \mathrm{O}$ response and other stalagmite $\delta^{18} \mathrm{O}$ responses around the IPWP are present in a simulated climate with water isotopes, and if so what atmospheric mechanism causes rainfall variability over the Sunda Shelf in the model simulation. We compare the recent isotope-equipped transient simulation's Heinrich Stadial event response with two other state-of-the-art climate model simulations to review model

This article is protected by copyright. All rights reserved. 
consistency. We aim to reconcile evidence learned from the real world and model world to gain new physical insights on how IPWP convection responded to orbital forcing as well as significant changes to the AMOC over the North Atlantic.

\section{Methods}

\subsection{Site Location}

The stalagmite presented in this study, SC02, was collected from Secret Cave in Gunung Mulu National Park, which is southwest-adjacent to Gunung Buda National Park in northern Borneo (Supporting Information Text S1, Figure S1). The site sits in the center of the tropical convection zone, today receiving $\sim 5000 \mathrm{~mm}$ rainfall annually, with little seasonal variability in either temperature or rainfall amount. Over a decade of daily rainwater and biweekly drip water monitoring shows a small deviation to higher rainwater $\delta^{18} \mathrm{O}$ values in the February-March-April months (Figure 1). The linear regression correlation coefficient between annually averaged $\delta^{18} \mathrm{O}$ and rainfall amount at the study site is -0.67 , suggesting $\sim 45 \%$ of the variance in annual rainfall $\delta^{18} \mathrm{O}$ can be explained by variability in local interannual rainfall amount (Ellis et al., 2020). Dry local conditions associated with El Niño events are responsible for the largest interannual rainfall $\delta^{18} \mathrm{O}$ excursions at this site under modern conditions (Moerman et al., 2013; Ellis et al., 2020).

\subsection{Geochemical methods}

The U-Th age model for this study was constructed on the upper portion of stalagmite SC02 from 18 U-Th samples. Carolin et al. (2013; 2016) reported U-Th ages measured in the lower portion of stalagmite SC02, 105-31 ka (thousand years before 1950 C.E.). In the upper portion, four of the $18 \mathrm{U}$-Th samples were analyzed in the Division of Geological and Planetary Sciences at the California Institute of Technology, and 14 samples were analyzed in the Department of Earth Sciences at the University of Oxford, following the methods of Carolin et al. (2016; 2019). A detailed description of the U-Th age sampling, multicollector inductively-coupled-plasma mass spectrometer (MC-ICP-MS) measurements, and sample age error analysis is found in Supporting Information Text S2.

Previous studies have found a wide range of initial detrital ${ }^{230} \mathrm{Th} /{ }^{232} \mathrm{Th}$ values in Buda and Mulu stalagmites, which are used to correct for any detrital ${ }^{230} \mathrm{Th}$ captured within the calcite crystals during formation. Individual isochrons suggest values from 45 to $200 \mathrm{ppm}$ as atom ratios (or 8 to 37 as activity ratios) (Partin et al., 2007; Carolin et al., 2013; Carolin et al., 2016; Chen et al., 2016), several times larger than the commonly used bulk surface silicate ${ }^{230} \mathrm{Th} /{ }^{232} \mathrm{Th}$ value of $\sim 5 \mathrm{ppm}$. The initial detrital ${ }^{230} \mathrm{Th} /{ }^{232} \mathrm{Th}$ value of $111 \pm 41 \mathrm{ppm}$ was previously calculated for SC02 based on two isochrons measured in separate stalagmites from Secret Cave in Mulu (methods and calculations in

This article is protected by copyright. All rights reserved. 
Carolin et al., 2013 Supplementary Materials), and is used here to correct the U-Th ages in the upper portion of SC02 for initial detrital Th contamination.

Stable isotope samples were milled along the growth axis of $\mathrm{SC0} 2$ in the Department of Earth Sciences at the University of Oxford using a New Wave Micromill. Samples were milled in a continuous trench style at $0.2 \mathrm{~mm}$ intervals around the YD calcite section and at $1 \mathrm{~mm}$ intervals in the other sections (Supporting Information Text S3). Samples were analyzed on a Delta V Advantage isotope ratio mass spectrometer coupled to either a Kiel IV carbonate device or Gas Bench II introductory system at the University of Oxford. Oxygen and carbon isotope results are given in parts per mill (\%o) relative to the Vienna Pee Dee Belemnite Standard (VPDB). Average measurement error is less than $0.05 \%$ o $(1 \sigma)$ for $\delta^{13} \mathrm{C}$ and $0.10 \%$ o $(1 \sigma)$ for $\delta^{18} \mathrm{O}$. Interpolated ages at all stable isotope sample locations between individual U-Th age sample trenches were computed using the Poisson-process deposition model feature in OxCal(v4.4) (Bronk Ramsey, 2008, 2009; Ramsey \& Lee, 2013) (Supporting Information Text S4).

\subsection{Climate simulation}

For this study we compare stalagmite $\delta^{18} \mathrm{O}$ records with iTRACE (He et al., 2021a), a $20 \mathrm{ka}$ - $11 \mathrm{ka}$ transient simulation of global climate using the Community Earth System Model version 1.3 with fully coupled water isotope modules (iCESM) (Brady et al., 2019). The iTRACE simulation well reproduces the deglacial climate and water isotope evolution in the pan-Asian monsoon regions and Greenland (He et al. 2021a, b). The iTRACE experiments generally follow the strategy of the transient TraCE-21ka simulations (Liu et al., 2009; He et al., 2011), with meltwater flux designed to be largely consistent with reconstructed sea level change (Lambeck et al., 2014), continental ice sheets modified at the beginning of each 1000 year interval based on the ICE-6G reconstruction (Peltier et al., 2015), and greenhouse gases prescribed throughout following reconstructions (Petit et al., 1999; Lüthi et al., 2008; Schilt et al., 2010) (Fig. 2a in He et al., 2021a). At 14 ka, the bathymetry of the Sunda Shelf coast line shifts to the $75 \mathrm{~m}$ pre-industrial isobath, and at $12 \mathrm{ka}$, sea level rises further around the Sunda Shelf, according to ICE-6G (Peltier et al., 2015). As such, any abrupt shifts in the simulated climate at precisely $14 \mathrm{ka}$ and $12 \mathrm{ka}$ are discounted, as these are artifacts of the imposed abrupt coastline changes in the model at those times (He et al., 2021a). A full description of the model and its experiments can be found in He et al. (2021a) Supplementary Materials.

\section{Results}

\section{1 $\mathrm{SC} 02 \delta^{18} \mathrm{O}$ record}

Growth within the upper portion of SC02 spans the full deglaciation (Figure 2, Figure S2 and S3). The U-Th ages do not include any age reversals, with all ages within

This article is protected by copyright. All rights reserved. 
the sequential order of growth within error (Figure S3, Data Set S1). Vertical extension rate is slow but relatively constant, between 5-15 $\mu \mathrm{m} / \mathrm{yr}$ (Figure S3, Data Set S2).

Over orbital time scales ( $\sim 5 \mathrm{kyr})$, changes in $\delta^{18} \mathrm{O}$ in SC02 match those in the original Buda $\delta^{18} \mathrm{O}$ record (Partin et al., 2007), however millennial-scale $\delta^{18} \mathrm{O}$ shifts are most prominent in this study's $\mathrm{SC} 02$ record (Figure 2). The $\mathrm{SC} 02 \delta^{18} \mathrm{O}$ record's mean value is also the lowest of the group of four Mulu and Buda stalagmite records. Larger amplitude $\delta^{18} \mathrm{O}$ variability and lower mean $\delta^{18} \mathrm{O}$ values suggest this study's Mulu Secret Chamber stalagmite was least affected by mixing (Moerman et al., 2014; Ellis et al., 2020) and kinetic effects (Hendy, 1971).

The SC02 $\delta^{18} \mathrm{O}$ record looks similar to the original Buda Snail Shell Cave SCH02 $\delta^{18} \mathrm{O}$ record (Partin et al., 2007) on depth scale, however the $95 \%$ CI of the timing of onset and ending of $\delta^{18} \mathrm{O}$ events are not in alignment between the Mulu SC02 and original Buda SCH02 records (Figure S4). The disagreement between the Mulu SC02 and Buda SCH02 event timing is not caused by the initial detrital ${ }^{230} \mathrm{Th} /{ }^{232} \mathrm{Th}$ correction (Figure S4). We conclude that something inherent to the original Buda SCH02 sample geochemistry caused inaccuracies in calculated U-Th ages on millennial timescales, possibly related to the greater amount of detrital material, larger number of growth hiatuses, slow growth portions, uranium loss due to open-system behavior, or unresolved, short hiatuses found in this sample during certain time intervals. The inaccurate timing of certain millennial scale events in $\mathrm{SCH} 02$ could only be recognized through comparison with other same-site samples after the original publication.

The new SC02 $\delta^{18} \mathrm{O}$ record reveals for the first time evidence of abrupt northern Borneo stalagmite $\delta^{18} \mathrm{O}$ changes which overlap within age error, and appear similar to, the North Atlantic Bølling-Allerød onset ( 14.7 ka, e.g. Buizert et al., 2014), Younger Dryas onset (12.85 +/- 0.06 ka, Cheng et al., 2020), and Younger Dryas ending (11.70$11.61+/-0.04 \mathrm{ka}$, Cheng et al., 2020) (Figure S4).

\section{2 iTRACE IPWP model-data comparison}

Fig. 3 shows the full iTRACE simulated timeseries of rainfall and calculated calcite $\delta^{18} \mathrm{O}$, a function of rainfall $\delta^{18} \mathrm{O}$ and surface temperature (Supporting Information Text S5), compared with stalagmite $\delta^{18} \mathrm{O}$ from northern Borneo (stalagmite SC02) and five other sites around the IPWP (see Fig. 1 map), on a 50-yr moving mean of the annual average. The shape of the simulated rainfall variability around the northern Borneo site is remarkably similar to the SC02 stalagmite $\delta^{18} \mathrm{O}$ record (inverse relationship between Fig. $3 \mathrm{~b}$ left and middle columns) through the whole deglaciation, and there is also general agreement between the derived model calcite $\delta^{18} \mathrm{O}$ and the SC02 stalagmite $\delta^{18} \mathrm{O}$ record (Fig. 3b middle and right columns). The directional shift in $\delta^{18} \mathrm{O}$ in both northern and southern IPWP stalagmites is inversely related to each site's respective simulated rainfall shift during the deglaciation millennial events, changes consistent with the amount effect (e.g. Rozanski et al., 1993).

This article is protected by copyright. All rights reserved. 


\section{Discussion}

The regional coherence of multiple stalagmite $\delta^{18} \mathrm{O}$ deglaciation signals spaced throughout the maritime continent of the IPWP (Fig. 3) suggests broad-scale atmospheric dynamics, not local site-specific climate changes, drove the rainwater and stalagmite $\delta^{18} \mathrm{O}$ pattern. This interpretation is supported by the mean annual rainfall response simulated in iTRACE, in which the broad area of the Sunda Shelf north of the equator is drier, while the Indian Ocean south of the Sunda Shelf is wetter, in response to meltwater forcing and AMOC weakening simulated in the model (Fig. 3, Fig. S7).

The iTRACE IPWP mean annual rainfall response to North Atlantic freshwater forcing and a weakened AMOC is generally consistent with two other fully coupled general circulation climate model simulations: TraCE-21ka (Liu et al., 2009; He et al., 2011) and HadCM3 (Roberts and Hopcroft, 2020) (Fig. S8c). TraCE-21ka is a $21 \mathrm{ka}-$ modern transient simulation of global climate using the Community Climate System Model version 3 (CCSM3) (Collins et al., 2006). HadCM3 (Gordon et al., 2000; Pope et al., 2000) has been extensively used for climate studies since the late 1990s, and performs reasonably well with respect to mean climate (Valdes et al., 2017), particularly in the IPWP region under glacial conditions (DiNezio and Tierney, 2013). While the spatial rainfall anomaly pattern is consistent between all three simulations, the amplitude of the change in mean annual rainfall during the Heinrich event is much greater in the CESM1 (iTRACE) versus the CCSM3 simulation (Fig. S8c). The CESM1 mean annual rainfall response is similar in amplitude to the HadCM3 0.25 Sv forcing simulation (Fig. S8c). DiNezio et al. (2016) previously noted the agreement of IPWP paleoclimate proxies with both the CESM1 and HadCM3 simulated steady-state LGM climate. This study extends this agreement between proxy and model to include these two models' mean annual response to a North Atlantic freshwater forcing event.

The iTRACE simulated drying over Borneo during freshwater forcing events is largely caused by an anomalous local anticyclone in this model which shifts equatorward from the Philippine Sea over Borneo during the boreal winter months when AMOC is weakened (Fig. 4). This anticyclone was recently recognized in the iTRACE simulation in He et al. (2021c). The authors suggested that the anticyclone was yielded and persisted in boreal autumn by anomalously low moist static air from the midlatitudes, which was advected by mean northeasterly winds. The low moist static air results from an enhanced meridional sea surface temperature gradient in the Western North Pacific which is associated with a weakened AMOC state. During the winter months, these mean northeasterly winds strengthen, pushing the anticyclone southward over Borneo (Fig. 4 in He et al., 2021c), affecting both northern Borneo and nearby Palawan stalagmite locations in the model world (Fig. 4).

The western North Pacific anticyclone is also known to be sensitive to SST variability over the ENSO region and tropical Indian Ocean on interannual timescales (e.g. Wang et al., 2000; Xie et al., 2009; Li et al., 2017), events which have been observed to similarly cause significant rainfall anomalies over Borneo under modern conditions (e.g. Ropelewski and Halpert, 1987; Lau and Nath, 2003; Cobb et al., 2007). The simulated meridional SST change along the coast of East Asia, rather than the zonal SST in the ENSO region, coupled with the northeasterly wind flow, is shown in iTRACE simulations, as well as TraCE-21ka simulations, to also be able to produce such an anticyclone response (He et al., 2021c).

This article is protected by copyright. All rights reserved. 
The modeled boreal winter drying anomaly and rainwater $\delta^{18} \mathrm{O}$ anomaly over Borneo is stronger during HS1 versus the YD event (Fig. 4), and thus this season appears to have driven the stronger mean annual HS1 versus YD drying over Borneo in the model (Fig. S7). A larger deviation in northern Borneo stalagmite $\mathrm{SC} 02 \delta^{18} \mathrm{O}$ is also observed during HS1 versus the YD event, in support of the model results. Notably, while iTRACE simulates a weak drying over the Sunda Shelf north of the equator through boreal summer and an increase in austral summer rainfall over the Indian Ocean south of the Sunda Shelf during both HS1 and the YD, there is very little change in modeled rainwater $\delta^{18} \mathrm{O}$ over the Sunda Shelf during the boreal summer (Fig. S9). Future improvements in model isotope modules and further analysis using isotope tracers may help to better determine what factors are influencing rainwater $\delta^{18} \mathrm{O}$ over the Sunda Shelf during boreal summers as a result of meltwater forced events in the model world.

\section{Conclusions}

The new SC02 $\delta^{18} \mathrm{O}$ record provides better chronological constraints and continuous temporal coverage, as compared to previously published results, and reveals for the first time evidence of abrupt $\delta^{18} \mathrm{O}$ changes in northern Borneo coincident with the North Atlantic BøllingAllerød onset and the Younger Dryas millennial event. The record affirms the regional consistency amongst multiple stalagmite $\delta^{18} \mathrm{O}$ deglaciation records throughout the maritime continent, suggesting broad-scale atmospheric dynamics drove the records' $\delta^{18} \mathrm{O}$ pattern. A comparison of the spatial and temporal pattern of the stalagmite $\delta^{18} \mathrm{O}$ records with a recent isotope-equipped transient simulation shows general mean annual model-data agreement at most stalagmite sites in the IPWP. The anomalous drying over Borneo during HS1 and the YD is attributed to an anomalous Western North Pacific anticyclone found in the iTRACE and TraCE$21 \mathrm{ka}$ simulations when AMOC is in a weakened state, which shifts south over Borneo during winter months. The distinct spatial and temporal IPWP $\delta^{18} \mathrm{O}$ signature over the last deglaciation captured in the IPWP stalagmite $\delta^{18} \mathrm{O}$ records presents a robust regional target for future isotopeenabled climate model experiments.

\section{Figure Captions}

Figure 1. Location of study site (circled) and other stalagmite paleoclimate sites in the text: Palawan, $10^{\circ} \mathrm{N}$ (Partin et al., 2015); Borneo, $4^{\circ} \mathrm{N}$ (this study); Sumatra, $0^{\circ} \mathrm{S}$ (Wurtzel et al., 2018); Sulawesi, $5^{\circ} \mathrm{S}$ (Krause et al., 2019); Flores, $8.5^{\circ} \mathrm{S}$ (Griffiths et al., 2009; Ayliffe et al., 2013); Western Australia, $17^{\circ} \mathrm{S}$ (Denniston et al., 2013). Triangle symbols indicate cave site is predominantly boreal (up) or austral (down) summer rainfall. Circle symbol sites have little rainfall seasonality. Contours show mean annual sea surface temperatures (SST) (Hersbach et al., 2019). Black filled shapes show modern landmasses, with the grey contours at 60 meters below sea level modern bathymetry, indicating the estimated Younger Dryas event coastlines. Long term average (2006-2018) monthly rainfall $\delta^{18} \mathrm{O}$ with $1 \sigma$ error bars at this study site are shown on the right (Moerman et al., 2013; Ellis et al., 2020). Note the y-axis is inverted.

Figure 2. (a) SC02 (this study; black) and BA04, SSC01, and SCH02 (Partin et al., 2007; green, red, and blue, respectively) $\delta^{18} \mathrm{O}$ records, plotted on a single y-axis. (b) Individual SC02 (this study), and BA04, SSC01, and SCH02 (Partin et al., 2007) $\delta^{18} \mathrm{O}$ records. For both (a) and (b), the $\mathrm{BA} 04, \mathrm{SSC} 01$, and $\mathrm{SCH} 02$ records are plotted on their originally published age models. U-Th

This article is protected by copyright. All rights reserved. 
ages of all samples were corrected using the mean initial detrital ${ }^{230} \mathrm{Th} /{ }^{232} \mathrm{Th}$ listed. Solid black vertical lines in (b) are at 14.7, 12.87, and $11.7 \mathrm{ka}$.

Figure 3. iTRACE and IPWP region stalagmite $\delta^{18} \mathrm{O}$ records. (i) iTRACE annual precipitation at 50-yr moving mean (He et al., 2021a) averaged from grid cells near respective stalagmite sites (Figure S5). (ii) Stalagmite $\delta^{18} \mathrm{O}$ at sampling resolution published: (a) Partin et al., 2015, (b) this study, (c) Wurtzel et al., 2018, (d) Krause et al., 2019, (e) Griffiths et al., 2009, Ayliffe et al., 2013, (f) Denniston et al., 2013. (iii) Light blue: iTRACE precipitation-weighted annual precipitation $\delta^{18} \mathrm{O}$ at 50-yr moving mean (He et al., 2021a) averaged from grid cells near respective stalagmite sites (Figure S5). Dark blue: Forward-modeled calcite $\delta^{18} \mathrm{O}$, a function of iTRACE-simulated rainfall $\delta^{18} \mathrm{O}$ and surface temperature (Supporting Information Text S5). The plotted size of $\mathrm{y}$-axis tick intervals is the same between stalagmite and modeled $\delta^{18} \mathrm{O}$ for each respective site. Grey bars indicate timing of HS1 (18-14.7 ka) and the YD (12.87-11.7 ka).

Figure 4. iTRACE modeled change in seasonal rainfall in response to YD and HS1 forcing in the IPWP. (a) "Heinrich event" 15.5-15 ka 500-yr monthly mean minus "background" 20-19 ka 1000-yr monthly mean and (b) "YD" 12.5-12 ka 500-yr monthly mean minus "background" 13.5-13 ka 500-yr monthly mean rainfall for the indicated 3-month period. Black outline is modern bathymetry at (a) 120 meters below sea level today and (b) 60 meters below sea level today, indicating estimated Heinrich 1 and Younger Dryas event coastlines, respectively. Arrows indicate low level wind anomalies $(850 \mathrm{hPa})$. Markers indicate cave site locations, same as Fig. 1 .

\section{Acknowledgments}

We wish to thank all of the staff, freelance guides, and locals at Gunung Mulu National Park for their assistance in field work and sample collection over the past 15+ years. Thank you to David Battisti for his efforts in assisting select authors of this article with computation and model analysis basics in preparation for this project. Thank you to Alan Hsieh and Andrew Mason at the University of Oxford, and Guillaume Paris and Sophie Hines when at Caltech for their assistance with U-Th analysis. Thank you to Gideon Henderson for his support and encouragement, and to Nele Meckler, Yves Krüger, and Marit Løland for helpful discussion. Thank you to the reviewers for their time and comments. Permits for this work were granted by the Malaysian Economic Planning Unit, the Sarawak State Planning Unit, and the Sarawak Forestry Department. This work was supported by a Geological Society 2017 Research Grant (UK) and a Royal Society International Exchanges Award (UK).

\section{Open Research}

All data are publicly available on NOAA NCDC (https://www.ncei.noaa.gov/access/paleosearch/study/35433) and Zenodo (https://doi.org/10.5281/zenodo.6026615). The authors acknowledge no conflicts of interest.

\section{References}

Adler, R.F., G.J. Huffman, A. Chang, R. Ferraro, P. Xie, J. Janowiak, B. Rudolf, U. Schneider, S. Curtis, D. Bolvin, A. Gruber, J. Susskind, and P. Arkin, 2003: The Version 2 Global

This article is protected by copyright. All rights reserved. 
Precipitation Climatology Project (GPCP) Monthly Precipitation Analysis (1979-Present). J. Hydrometeor., 4,1147-1167. GPCP Precipitation data provided by the NOAA/OAR/ESRL PSL, Boulder, Colorado, USA, from their website at https://psl.noaa.gov/data/gridded/data.gpcp.html. Ayliffe, L. K., Gagan, M. K., Zhao, J., Drysdale, R. N., Hellstrom, J. C., Hantoro, W. S., et al. (2013), Rapid interhemispheric climate links via the Australasian monsoon during the last deglaciation. Nature Communications, 4(1), 2908. https://doi.org/10.1038/ncomms3908 Belgaman, H. A., Ichiyanagi, K., Suwarman, R., Tanoue, M., Aldrian, E., Utami, A. I. D., \& Kusumaningtyas, S. D. A. (2017), Characteristics of seasonal precipitation isotope variability in Indonesia. Hydrological Research Letters, 11(2), 92-98. https://doi.org/10.3178/hrl.11.92

Böhm, E., Lippold, J., Gutjahr, M., Frank, M., Blaser, P., Antz, B., et al. (2015), Strong and deep Atlantic meridional overturning circulation during the last glacial cycle. Nature, 517(7532), 7376. https://doi.org/10.1038/nature14059

Brady, E., Stevenson, S., Bailey, D., Liu, Z., Noone, D., Nusbaumer, J., et al. (2019), The Connected Isotopic Water Cycle in the Community Earth System Model Version 1. Journal of Advances in Modeling Earth Systems, 11(8), 2547-2566. https://doi.org/10.1029/2019MS001663 Bronk Ramsey, C. (2008), Deposition models for chronological records. Quaternary Science Reviews, 27(1-2), 42-60. https://doi.org/10.1016/j.quascirev.2007.01.019

Bronk Ramsey, C. (2009), Bayesian Analysis of Radiocarbon Dates. Radiocarbon, 51(01), 337360. https://doi.org/10.1017/S0033822200033865

Bronk Ramsey, C., \& Lee, S. (2013), Recent and Planned Developments of the Program OxCal. Radiocarbon, 55(02), 720-730. https://doi.org/10.1017/S0033822200057878

This article is protected by copyright. All rights reserved. 
Buizert, C., Gkinis, V., Severinghaus, J. P., He, F., Lecavalier, B. S., Kindler, P., et al. (2014), Greenland temperature response to climate forcing during the last deglaciation. Science, 345(6201), 1177-1180. https://doi.org/10.1126/science.1254961

Carolin, S. A., Cobb, K. M., Adkins, J. F., Clark, B., Conroy, J. L., Lejau, S., et al. (2013), Varied Response of Western Pacific Hydrology to Climate Forcings over the Last Glacial Period. Science, 340(6140), 1564-1566. https://doi.org/10.1126/science.1233797

Carolin, S. A., Cobb, K. M., Lynch-Stieglitz, J., Moerman, J. W., Partin, J. W., Lejau, S., et al. (2016), Northern Borneo stalagmite records reveal West Pacific hydroclimate across MIS 5 and 6. Earth and Planetary Science Letters, 439, 182-193. https://doi.org/10.1016/j.eps1.2016.01.028 Carolin, S. A., Ersek, V., Roberts, W. H. G., Walker, R. T., \& Henderson, G. M. (2019), Drying in the Middle East During Northern Hemisphere Cold Events of the Early Glacial Period.

Geophysical Research Letters, 46(23), 14003-14010. https://doi.org/10.1029/2019GL084365

Chen, S., Hoffmann, S. S., Lund, D. C., Cobb, K. M., Emile-Geay, J., \& Adkins, J. F. (2016), A high-resolution speleothem record of western equatorial Pacific rainfall: Implications for Holocene ENSO evolution. Earth and Planetary Science Letters, 442, 61-71.

https://doi.org/10.1016/j.eps1.2016.02.050

Cheng, H., Lawrence Edwards, R., Shen, C.-C., Polyak, V. J., Asmerom, Y., Woodhead, J., et al. (2013). Improvements in 230Th dating, 230Th and 234U half-life values, and U-Th isotopic measurements by multi-collector inductively coupled plasma mass spectrometry. Earth and Planetary Science Letters, 371-372, 82-91. https://doi.org/10.1016/j.epsl.2013.04.006 Cheng, H., Zhang, H., Spötl, C., Baker, J., Sinha, A., Li, H., et al. (2020), Timing and structure of the Younger Dryas event and its underlying climate dynamics. Proceedings of the National Academy of Sciences, 117(38), 23408-23417. https://doi.org/10.1073/pnas.2007869117

This article is protected by copyright. All rights reserved. 
Cobb, K. M., Adkins, J. F., Partin, J. W., \& Clark, B. (2007). Regional-scale climate influences on temporal variations of rainwater and cave dripwater oxygen isotopes in northern Borneo. Earth and Planetary Science Letters, 263(3-4), 207-220. https://doi.org/10.1016/j.eps1.2007.08.024

Collins, W. D., Bitz, C. M., Blackmon, M. L., Bonan, G. B., Bretherton, C. S., Carton, J. A., et al. (2006), The Community Climate System Model Version 3 (CCSM3). Journal of Climate, 19(11), 2122-2143. https://doi.org/10.1175/JCLI3761.1

Daëron, M., Drysdale, R. N., Peral, M., Huyghe, D., Blamart, D., Coplen, T. B., et al. (2019). Most Earth-surface calcites precipitate out of isotopic equilibrium. Nature Communications, 10(1), 429. https://doi.org/10.1038/s41467-019-08336-5

DiNezio, P. N., \& Tierney, J. E. (2013), The effect of sea level on glacial Indo-Pacific climate. Nature Geoscience, 6(6), 485-491. https://doi.org/10.1038/ngeo1823

DiNezio, P. N., Timmermann, A., Tierney, J. E., Jin, F.-F., Otto-Bliesner, B., Rosenbloom, N., et al. (2016), The climate response of the Indo-Pacific warm pool to glacial sea level.

Paleoceanography, 31(6), 866-894. https://doi.org/10.1002/2015PA002890

Denniston, R. F., Wyrwoll, K.-H., Asmerom, Y., Polyak, V. J., Humphreys, W. F., Cugley, J., et al. (2013), North Atlantic forcing of millennial-scale Indo-Australian monsoon dynamics during the Last Glacial period. Quaternary Science Reviews, 72, 159-168. https://doi.org/10.1016/j.quascirev.2013.04.012 Du, X., Russell, J. M., Liu, Z., Otto-Bliesner, B. L., Gao, Y., Zhu, C., et al. (2021). Deglacial trends in Indo-Pacific warm pool hydroclimate in an isotope-enabled Earth system model and implications for isotope-based paleoclimate reconstructions. Quaternary Science Reviews, 270, 107188. https://doi.org/10.1016/j.quascirev.2021.107188

This article is protected by copyright. All rights reserved. 
Ellis, S. A., Cobb, K. M., Moerman, J. W., Partin, J. W., Bennett, A. L., Malang, J., et al. (2020), Extended Cave Drip Water Time Series Captures the 2015-2016 El Niño in Northern Borneo. Geophysical Research Letters, 47(5). https://doi.org/10.1029/2019GL086363

Gordon, C., Cooper, C., Senior, C. A., Banks, H., Gregory, J. M., Johns, T. C., et al. (2000), The simulation of SST, sea ice extents and ocean heat transports in a version of the Hadley Centre coupled model without flux adjustments. Climate Dynamics, 16(2-3), 147-168.

https://doi.org/10.1007/s003820050010

Griffiths, M. L., Drysdale, R. N., Gagan, M. K., Zhao, J. -x., Ayliffe, L. K., Hellstrom, J. C., et al. (2009), Increasing Australian-Indonesian monsoon rainfall linked to early Holocene sea-level rise. Nature Geoscience, 2(9), 636-639. https://doi.org/10.1038/ngeo605

Hanebuth, T., Stattegger, K., \& Grootes, P. M. (2000), Rapid Flooding of the Sunda Shelf: A Late-Glacial Sea-Level Record. Science, 288(5468), 1033-1035.

https://doi.org/10.1126/science.288.5468.1033

He, C., Liu, Z., Otto-Bliesner, B. L., Brady, E. C., Zhu, C., Tomas, R., et al. (2021a), Hydroclimate footprint of pan-Asian monsoon water isotope during the last deglaciation. Science Advances, 7(4), eabe2611. https://doi.org/10.1126/sciadv.abe2611

He, C., Liu, Z., Otto-Bliesner, B. L., Brady, E. C., Zhu, C., Tomas, R., et al. (2021b), Abrupt Heinrich Stadial 1 cooling missing in Greenland oxygen isotopes. Science Advances, 7(25), eabh1007. https://doi.org/10.1126/sciadv.abh1007

He, C., Liu, Z., Otto-Bliesner, B. L., Brady, E. C., Zhu, C., Tomas, R., et al. (2021c), Deglacial variability of South China hydroclimate heavily contributed by autumn rainfall. Nature Communications, 12(1), 5875. https://doi.org/10.1038/s41467-021-26106-0

This article is protected by copyright. All rights reserved. 
He, F. (2011), Simulating Transient Climate Evolution of the Last Deglaciation with CCSM3. PhD thesis, Univ. Wisconsin-Madison.

Hersbach, H., Bell, B., Berrisford, P., Biavati, G., Horányi, A., Muñoz Sabater, J., Nicolas, J., Peubey, C., Radu, R., Rozum, I., Schepers, D., Simmons, A., Soci, C., Dee, D., Thépaut, J-N. (2019), ERA5 monthly averaged data on single levels from 1979 to present. Copernicus Climate Change Service (C3S) Climate Data Store (CDS). https://doi.org/10.24381/CDS.F17050D7 Hendy, C. H. (1971), The isotopic geochemistry of speleothems-I. The calculation of the effects of different modes of formation on the isotopic composition of speleothems and their applicability as palaeoclimatic indicators. Geochimica et Cosmochimica Acta, 35(8), 801-824. https://doi.org/10.1016/0016-7037(71)90127-X

Kim, S.-T., \& O’Neil, J. R. (1997). Equilibrium and nonequilibrium oxygen isotope effects in synthetic carbonates. Geochimica et Cosmochimica Acta, 61(16), 3461-3475. https://doi.org/10.1016/S0016-7037(97)00169-5

Kim, S.-T., Coplen, T. B., \& Horita, J. (2015). Normalization of stable isotope data for carbonate minerals: Implementation of IUPAC guidelines. Geochimica et Cosmochimica Acta, 158, 276289. https://doi.org/10.1016/j.gca.2015.02.011

Konecky, B. L., Noone, D. C., \& Cobb, K. M. (2019). The Influence of Competing Hydroclimate Processes on Stable Isotope Ratios in Tropical Rainfall. Geophysical Research Letters, 46(3), 1622-1633. https://doi.org/10.1029/2018GL080188

Krause, C. E., Gagan, M. K., Dunbar, G. B., Hantoro, W. S., Hellstrom, J. C., Cheng, H., et al. (2019), Spatio-temporal evolution of Australasian monsoon hydroclimate over the last 40,000 years. Earth and Planetary Science Letters, 513, 103-112.

https://doi.org/10.1016/j.eps1.2019.01.045

This article is protected by copyright. All rights reserved. 
Lambeck, K., Rouby, H., Purcell, A., Sun, Y., \& Sambridge, M. (2014). Sea level and global ice volumes from the Last Glacial Maximum to the Holocene. Proceedings of the National Academy of Sciences, 111(43), 15296-15303. https://doi.org/10.1073/pnas.1411762111

Lau, N.-C., \& Nath, M. J. (2003). Atmosphere-Ocean Variations in the Indo-Pacific Sector during ENSO Episodes. Journal of Climate, 16(1), 3-20. https://doi.org/10.1175/15200442(2003)016<0003:AOVITI>2.0.CO;2

Li, T., Wang, B., Wu, B., Zhou, T., Chang, C.-P., \& Zhang, R. (2017), Theories on formation of an anomalous anticyclone in western North Pacific during El Niño: A review. Journal of Meteorological Research, 31(6), 987-1006. https://doi.org/10.1007/s13351-017-7147-6

Liu, Z., Otto-Bliesner, B. L., He, F., Brady, E. C., Tomas, R., Clark, P. U., et al. (2009), Transient Simulation of Last Deglaciation with a New Mechanism for Bolling-Allerod Warming. Science, 325(5938), 310-314. https://doi.org/10.1126/science.1171041 Lüthi, D., Le Floch, M., Bereiter, B., Blunier, T., Barnola, J.-M., Siegenthaler, U., et al. (2008). High-resolution carbon dioxide concentration record 650,000-800,000 years before present. Nature, 453(7193), 379-382. https://doi.org/10.1038/nature06949 McManus, J. F., Francois, R., Gherardi, J.-M., Keigwin, L. D., \& Brown-Leger, S. (2004), Collapse and rapid resumption of Atlantic meridional circulation linked to deglacial climate changes. Nature, 428(6985), 834-837. https://doi.org/10.1038/nature02494 Moerman, J. W., Cobb, K. M., Adkins, J. F., Sodemann, H., Clark, B., \& Tuen, A. A. (2013), Diurnal to interannual rainfall $\delta 180$ variations in northern Borneo driven by regional hydrology. Earth and Planetary Science Letters, 369-370, 108-119. https://doi.org/10.1016/j.epsl.2013.03.014

This article is protected by copyright. All rights reserved. 
Ng, H. C., Robinson, L. F., McManus, J. F., Mohamed, K. J., Jacobel, A. W., Ivanovic, R. F., et al. (2018), Coherent deglacial changes in western Atlantic Ocean circulation. Nature Communications, 9(1), 2947. https://doi.org/10.1038/s41467-018-05312-3

Partin, Judson W., Cobb, K. M., Adkins, J. F., Clark, B., \& Fernandez, D. P. (2007), Millennialscale trends in west Pacific warm pool hydrology since the Last Glacial Maximum. Nature, 449(7161), 452-455. https://doi.org/10.1038/nature06164

Partin, J.W., Quinn, T. M., Shen, C.-C., Okumura, Y., Cardenas, M. B., Siringan, F. P., et al. (2015), Gradual onset and recovery of the Younger Dryas abrupt climate event in the tropics. Nature Communications, 6, 8061. https://doi.org/10.1038/ncomms9061

Peltier, W. R., Argus, D. F., \& Drummond, R. (2015), Space geodesy constrains ice age terminal deglaciation: The global ICE-6G_C (VM5a) model: Global Glacial Isostatic Adjustment. Journal of Geophysical Research: Solid Earth, 120(1), 450-487.

https://doi.org/10.1002/2014JB011176

Petit, J. R., Jouzel, J., Raynaud, D., Barkov, N. I., Barnola, J.-M., Basile, I., et al. (1999). Climate and atmospheric history of the past 420,000 years from the Vostok ice core, Antarctica. Nature, 399(6735), 429-436. https://doi.org/10.1038/20859

Pope, V. D., Gallani, M. L., Rowntree, P. R., \& Stratton, R. A. (2000), The impact of new physical parametrizations in the Hadley Centre climate model: HadAM3. Climate Dynamics, 16(2-3), 123-146. https://doi.org/10.1007/s003820050009

Roberts, W. H. G., \& Hopcroft, P. O. (2020), Controls on the Tropical Response to Abrupt Climate Changes. Geophysical Research Letters, 47(6). https://doi.org/10.1029/2020GL087518

This article is protected by copyright. All rights reserved. 
Ropelewski, C. F., \& Halpert, M. S. (1987). Global and Regional Scale Precipitation Patterns Associated with the El Niño/Southern Oscillation. Monthly Weather Review, 115(8), 1606-1626. https://doi.org/10.1175/1520-0493(1987)115<1606:GARSPP>2.0.CO;2

Rozanski, K., Araguas-Araguas, L., Gonfiantini, R., 1993. Isotopic patterns in modern global precipitation. In: Swart, P.K., Lohmann, K.C., McKenzie, J. (Eds.), Climate Change in Continental Isotopic Records. Geophysical Monograph, vol. 78. American Geophysical Union, Washington, DC, pp. 1-36.

Schilt, A., Baumgartner, M., Blunier, T., Schwander, J., Spahni, R., Fischer, H., \& Stocker, T. F. (2010). Glacial-interglacial and millennial-scale variations in the atmospheric nitrous oxide concentration during the last 800,000 years. Quaternary Science Reviews, 29(1-2), 182-192. https://doi.org/10.1016/j.quascirev.2009.03.011

Tremaine, D. M., Froelich, P. N., \& Wang, Y. (2011). Speleothem calcite farmed in situ: Modern calibration of $\delta 180$ and $\delta 13 \mathrm{C}$ paleoclimate proxies in a continuously-monitored natural cave system. Geochimica et Cosmochimica Acta, 75(17), 4929-4950.

https://doi.org/10.1016/j.gca.2011.06.005

Timmermann, A., Okumura, Y., An, S.-I., Clement, A., Dong, B., Guilyardi, E., et al. (2007).

The Influence of a Weakening of the Atlantic Meridional Overturning Circulation on ENSO. Journal of Climate, 20(19), 4899-4919. https://doi.org/10.1175/JCLI4283.1

Valdes, P. J., Armstrong, E., Badger, M. P. S., Bradshaw, C. D., Bragg, F., Crucifix, M., et al. (2017), The BRIDGE HadCM3 family of climate models: HadCM3@Bristol v1.0. Geoscientific Model Development, 10(10), 3715-3743. https://doi.org/10.5194/gmd-10-3715-2017

This article is protected by copyright. All rights reserved. 
Wang, B., Wu, R., \& Fu, X. (2000). Pacific-East Asian Teleconnection: How Does ENSO Affect East Asian Climate? Journal of Climate, 13(9), 1517-1536. https://doi.org/10.1175/15200442(2000)013<1517:PEATHD $>2.0 . C O ; 2$

Wang, Y. J., Cheng, H., Edwards, R. L., An, Z. S., Wu, J. Y., Shen, C.-C., \& Dorale, J. A. (2001), A High-Resolution Absolute-Dated Late Pleistocene Monsoon Record from Hulu Cave, China. Science, 294(5550), 2345. https://doi.org/10.1126/science.1064618

Wang, C. (2019). Three-ocean interactions and climate variability: a review and perspective. Climate Dynamics, 53(7-8), 5119-5136. https://doi.org/10.1007/s00382-019-04930-x

Windler, G., Tierney, J. E., Zhu, J., \& Poulsen, C. J. (2020). Unraveling Glacial Hydroclimate in the Indo- Pacific Warm Pool: Perspectives From Water Isotopes. Paleoceanography and Paleoclimatology, 35(12). https://doi.org/10.1029/2020PA003985

Wurtzel, J. B., Abram, N. J., Lewis, S. C., Bajo, P., Hellstrom, J. C., Troitzsch, U., \& Heslop, D. (2018), Tropical Indo-Pacific hydroclimate response to North Atlantic forcing during the last deglaciation as recorded by a speleothem from Sumatra, Indonesia. Earth and Planetary Science Letters, 492, 264-278. https://doi.org/10.1016/j.epsl.2018.04.001

Xie, S.-P., Hu, K., Hafner, J., Tokinaga, H., Du, Y., Huang, G., \& Sampe, T. (2009). Indian

Ocean Capacitor Effect on Indo-Western Pacific Climate during the Summer following El Niño. Journal of Climate, 22(3), 730-747. https://doi.org/10.1175/2008JCLI2544.1

Zhang, R., \& Delworth, T. L. (2005). Simulated Tropical Response to a Substantial Weakening of the Atlantic Thermohaline Circulation. Journal of Climate, 18(12), 1853-1860. https://doi.org/10.1175/JCLI3460.1

This article is protected by copyright. All rights reserved. 
Zhang, R., \& Delworth, T. L. (2007). Impact of the Atlantic Multidecadal Oscillation on North Pacific climate variability. Geophysical Research Letters, 34(23).

https://doi.org/10.1029/2007GL031601

This article is protected by copyright. All rights reserved. 